\title{
The Genetic Improvement of Sorghum in Ethiopia: Review
}

\author{
Zigale Semahegn Yitayeh \\ Department of Horticulture and Plant Science, Jimma university, Jimma, P.O., Box 307, Ethiopia
}

\begin{abstract}
Sorghum is the most known drought tolerant crop as compared to other cereal crops due to it's ability to withstand poor soil fertility and high temperature. As Ethiopia is the centre of origin and diversity for sorghum, the crop has been cultivated for thousands of years and hence the heritage of the crop is expected to be rich. Sorghum is mostly grown as food grain in the developing country while in the developed countries, as an animal feed. The yield and quality of sorghum is affected by many factors such as drought, Striga, insect pests (stalk borer, midge, and shoot fly), disease (grain mold, anthracnose and smut). Ethiopia has a diverse sorghum germplasm which adapted to a range of altitudes and rainfall conditions. Characterization and identification of sorghum germplasms which provide desirable traits for genetic improvement is a basis in plant breeding. DNA based molecular marker and PCR based are the best to characterize and identify sorghum genotypes which provide desirable traits as compared to field experimental evaluation due to time and environmental effect. Genetic improvement is the cost-effective means of enhancing sorghum productivity for different end-uses. In Ethiopia, sorghum improvement for yield,quality, early mature, biomass, resistance to drought, Striga, diseases and wide adaptability prioritized by national sorghum improvement program to satisfy end-users demand. Fifty two sorghum vareites, which contained desirable traits as compared to landraces, released in Ethiopia.
\end{abstract}

Keywords: Sorghum breeding, genetic diversity, sorghum improvement, genetic variablity

DOI: $10.7176 / \mathrm{JBAH} / 9-3-06$

\section{Introduction}

Sorghum (Sorghum bicolor L. Moench) is a C4 tropical crop (Dillon et al., 2007; Smith and Frederiksen, 2000, Mindaye TT et al., 2015). It is able to withstand low soil fertility and high temperature conditions (Tolk et al., 2013).

Sorghum is an indigenous crop to Ethiopia, which is the sixth largest sorghum producing country in the world with sorghum contributing $16.4 \%$ of the total annual cereal grain production and is ranked third in both total area coverage and productivity (CSA, 2017). Currently, the national average productivity of sorghum in Ethiopia is 2.5 tons/ha (CSA, 2017).

In the arid and semi-arid tropics of Africa and Asia, sorghum is mostly grown as a food grain crop while in the developed world the majority of the grain produced is used for animal feed (Rakshit et al., 2014). Sorghum grain is preferred next to tef, a small cereal grain crop, for the preparation of the staple leavened bread (injera). The grain has also use for the preparation of locally prepared beverages. In addition, the stover is equally valued as the grain, which can be used as animal feed, fuel wood and construction purposes.

Current rate of yield and production advance in sorghum is not adequate. Drought is one of the major yield limiting factors. Over eighty percent of sorghum in Ethiopia is produced under sever to moderate drought stress condition (EIAR, 2014). A major challenge of sorghum production in these parts of the country is lack of high yielding and stable varieties, lack of improvement works in genetic yield potential , abiotic stresses such as drought, soil fertility decline (Gebrekidan H., 2003). In addition, Biotic stresses such as diseases, insects and weeds (especially Striga) are also yield limiting factors. Therefore, this paper was prepared with the objectives of reviewing the genetic improvement of sorghum in Ethiopia

\subsection{Origin, distribution and adaptability of sorghum}

Ethiopia is the Vavilovian centers origin/diversity for sorghum (Vavilov, 1951). Sorghum originated in Africa, more known in Ethiopia, between 5000 and 7000 years ago (ICRISAT, 2005). Then, it was distributed along the trade and shipping routes around the African continent, and through the Middle East to India at least 3000 years ago. It then journeyed along the Silk Route into China (Dicko et al., 2006). It was first taken to North America in the 1700-1800's through the slave trade from West Africa and was re-introduced in Africa in the late $19^{\text {th }}$ century for commercial cultivation and spread to South America and Australia.

Currently sorghum is widely found in the dry lowland areas of Africa, Asia (India and China), the Americas and Australia (Dicko et al., 2006). It is an economically, socially and culturally important crop grown over a wide range of ecological habitats in Ethiopia, in the range of 400-3000 m.a.s.l (Teshome et al., 2007). Sorghum is a unique cereal crop in the lowland areas due to its drought tolerance (Kebede, 1991).

\subsection{Botany and Taxonomy of Sorghum}

The genus Sorghum has been classified into fivesubgenera: Eu-sorghum,Chaetosorghum, Heterosorghum, Para- 
sorghum and Stiposorghum. Although this classification is convenient, however it does not stand for evolutionary relationships (Dillon et al., 2004). The Eu-sorghum comprises the cultivated species S. Bicolor (L.) Moench and its subspecies are drummondii, arundinaceum, and wild species includes S. xalum Parodi, S. halepense (L.) Pers. and S. propinquum (deWet, 1978). The Eu-sorghum section is originated from Africa or Asia Doggett (1976), DuVall and Doebley (1990). Sections Chaetosorghum and Heterosorghum consist of S. macrospermum and $S$. Laxiflorum and both of these species are annuals and polyploids (Lazarides et al., 1991). Section Stiposorghum includes ten species (Lazarides et al. 1991). Para-sorghum Section is comprised seven African, Asian, Australian and Central American species. The basic number of chromosome of species in each section is five. The species belong to Para sorghum and Stiposorghum are mostly diploid $(2 \mathrm{n}=20)$, however a few species are tetraploid or hexaploid.

Sorghum includes three species, S. halepense, S. propinquum and S. bicolor. Sorghum halepense is also known as Johnson grass, derived from a natural cross between S. arudinaceum and S. propinquum (Doggett, 1976). Sorghum propinquum is a perennial species related to S. bicolor (Sun et al., 1994). By using Harlan and deWet's system which is based on spikelet morphology, Sorghum bicolor has been classified into five races.

The five basic races of Sorghum bicolor are bicolor, guinea, caudatum, kafir and durra; and ten intermediate races under S. bicolor. It is a cereal of a remarkable genetic variability; with more than 30,000 selections present in the world genetic collections (Assefa and Staggenborg, 2010). Most of the tropical sorghums are short day plants and their response to day length is an important adaptation (Prasad and Staggenborg, 2009).

Grain sorghum belongs to the family of Poaceae, tribe Andopogoneae, sub-tribe Sorghinae, and genus Sorghum. In 1794, Moench established the genus Sorghum and brought the sorghums under the name S. bicolor. All cultivated sorghum belongs to Sorghum bicolor subsp. bicolor (Dicko et al., 2006).

\subsection{Importance of Sorghum \\ 2.3.1 Global Context}

As compared to other cereals, sorghum is a drought tolerant crop and able to withstand low soil fertility (Tolk et al., 2013, Mindaye TT et al., 2015). It is a main crop for more than 500 million people in the developing world mainly in the 30 sub Saharan Africa and Asian countries (Kumar et al., 2011), but it is also grown as a feed crop in the developed world. In addition, sorghum is a preferred feedstock for biofuel production due to its high biomass production and high water use efficiency (Packer and Rooney, 2014; Reddy et al., 2005a).

The sorghum production area globally has shown a mixed trend, and while the overall sorghum production area has declined from year to year mainly in USA, China and India, there is a steady increase in production area in most African countries (especially Sub Saharan Africa) and Australia (Rakshit et al., 2014). Sorghum productivity over the past four decades has shown a yield improvement of 1 to $4 \%$ per year in many countries including USA, Australia, and China

(Rakshit et al., 2014). The increased productivity of sorghum has maintained the total production and it has remained the fifth most important cereal crop in total grain production in the world (Kumar et al., 2011). The sorghum grain produced has contributed $2.7 \%$ of the top five major cereal grain produced globally over the past decade (FAOSTAT, 2015).

The increase in sorghum productivity is the outcome of both improved varieties and improved management practices. The use of hybrid varieties with improved management have been provided in yield increases that have been achieved in many developed and a few developing countries (Kumar et al., 2011; Smith and Frederiksen, 2000). To-date the total sorghum production area in USA and Australia is planted to hybrids and in China and India more than eighty five \% of sorghum growing areas is planted with improved varieties including hybrids (Reddy et al., 2006; Rakshit, 2014). The adoption of hybrids has contributed to increased sorghum productivity in many countries, for instance in China productivity has increased by $3.9 \%$ and in India by $2 \%$ per annum (Rakshit et al., 2014).

\subsubsection{Ethiopia Context}

Sorghum has diverse agro-ecological adaptation in Ethiopia and is cultivated in the three major Zones in the country which can be categorized into highlands $>1900$ meter above sea level (masl), intermediate between 16001900masl and lowland agro-ecologies $<1600$ masl (Kebede and Menkir, 1987; Tesso et al., 2011). It is the major crop in the dry lowlands which accounts for $66 \%$, on average, of the total cultivated areas of the country (Gebeyehu et al., 2004).

There are different systems of sorghum production that can be differentiated in relation to the amount of rainfall received and targeted uses (Gerorgis, 1990; Wortmann CS, 2009). Multiple cropping systems has been practiced in low moisture areas to reduce the effect of drought (Gerorgis, 1990) and sole cropping has been reported as the dominant cropping system in the major sorghum growing area of Ethiopia (Wortmann CS, 2009).

The majority of the grain produced $(74 \%)$ is used for household consumption and the remaining used for sale and seed purpose (CSA, 2014). Sorghum grain in Ethiopia is generally traded within the country (USAID, 2010). Sorghum grain is preferred next to teff for the preparation of the staple leavened bread (injera). Although there is 
variability in the grain quality depending on the end use product, larger seed size while light red types of sorghum grains are predominantly preferred for the preparation of injera. The grain has also use for the preparation of locally prepared beverages and the stover used as animal feed, fuel wood and construction purposes.

\subsection{Sorghum production constraints}

The national average sorghum productivity in Ethiopia is 2.5 tons/ha (CSA, 2017). Several production constraints were identified as hindrance for sorghum production and productivity enhancement. The major constraints include drought, Striga, insect pests (stalk borer, midge, and shoot fly), disease (grain mold, anthracnose and smut), soil fertility decline, inadequate adoption of the existing improved varieties, lack of high yielding and good quality sorghum varieties, and postharvest management practices (grain storage managements) such as storage pest control strategy and identifying alternative uses of sorghum grain.

\subsection{Sorghum genetic variability}

\subsubsection{Sorghum genetic variability in the world}

Characterization and identification of sorghum varieties which provide desirable traits for genetic improvement is a basis in plant breeding. Kimber et al. (2013) presented details of the major world sorghum collections and breeding lines of 150,000 accessions. Morphological variability of sorghum has been used for the development of sorghum core collections which represent the world collections to use in plant breeding (Grenier et al., 2000; Dahlberg et al., 2004, Mindaye TT et al., 2015). However, characterization and analysis of morphological traits and diversity of sorghum germplasm collections is too challenging due to time and environmental effects (Newbury and Ford-Lloyd, 1997).

The discovery of different types of DNA based molecular marker systems provided to characterize and structure large number of genotypes without any effect. Hybridization based RFLPs (Restricted Fragment Length Polymorphism) markers were the first DNA marker system identified that could differentiate homozygote and heterozygote loci (Botstein et al., 1980). RFLP markers have been used for genetic variability studies in different crops including in sorghum (Deu et al., 2006; Ahnert et al., 1996) and in maize (Pejic et al., 1998). The RFLP marker system is technically demanding, however, and found not to be suitable for high throughput and low cost screening.

The polymerase chain reaction (PCR) technique provide to increase both sample throughput and sample cost for marker screening. PCR based marker systems include RAPDs (Random Amplified Polymorphism) (Williams et al., 1990); AFLPs (Amplified Fragmented Length Polymorphism) (Vos et al., 1995) and SSRs (Simple Sequence Repeat) (Tautz et al., 1986) all of which have been widely used in various studies in many crops including in sorghum (Agrama and Tuinstra, 2003; Perumal et al., 2007) and maize (Garcia et al., 2004).

Both the hybridized and PCR based markers have had different applications to sorghum. A recent genetic variability study of global set of sorghum genotypes using SSR markers showed that landraces originating from Africa had the largest number of polymorphic alleles and the Eastern African genotypes had the highest variability followed by western African genotypes (Billot et al., 2013). Genetic variability and the genetic basis of racial classifications in sorghum have also been studied using different types of DNA based markers (Brown et al., 2011; Morris et al., 2013; Perumal et al., 2007; Ramu et al., 2013).

The next generation sequencing techniques (NGS) has offered new opportunities for sequencing and resequencing whole-genomes or targeted regions of genome (Edwards et al, 2013; Poland and Rife, 2012). Genotyping by sequencing (GBS) has been introduced as a tool to discover polymorphic markers while genotyping with high-throughput sequencing approaches with a low cost per data point (Gupta et al., 2008; Poland and Rife, 2012).

The recent resequencing of many sorghum genotypes showed the structuring of genotypes based on racial grouping and also identified genetic variability which could be useful for genetic improvements (Mace et al., 2013) In addition, genome wide markers generated by GBS have also been used for diversity analysis and understanding the genetic basis of complex traits and adaptation in sorghum (Morris et al., 2013; Wang et al., 2013).

\subsubsection{Sorghum genetic variability and potential in Ethiopia}

Ethiopia is a center of genetic diversity for many crops such as sorghum, barley, tef, chickpea and coffee, mostly represented in the country by landraces and wild types. Much of this crop diversity is found in small scale farmers, have played a great role in the creation, maintenance and efficient utilization of resources (Worede et al., 2000; Abe, 2010).

Ethiopia has a diverse sorghum germplasm which adapted to a range of altitudes and rainfall conditions. The five major races of sorghum have been identified in the Ethiopian sorghum collections, with the durra and bicolor types and their derived sub-races predominating (Cuevas and Prom, 2013; Doggett, 1988; Reddy et al., 2002; Teshome et al., 1997). The zerazera type of sorghum, which is the sub-type of the race caudatum, is known for its grain appearance or grain type and disease resistance (Prasada Rao and Mengesha, 1981). In addition to these, the Ethiopian sorghum collections have been used as a source of genes for important traits, including stay green genes 
for post flowering drought tolerance (Haussmann et al., 2002; Kebede et al., 2001), grain quality and increased yield potential (Prasada Rao and Mengesha, 1981) and high lysine and enhanced protein digestibility (Singh and Axtell, 1973) and starch digestibility (Gilding et al., 2013).

Analysis of genetic diversity is important for crop improvement and provides available genetic resources and a basis for stratified sampling of breeding populations (Mohammadi and Prasanna, 2003, Isaac K. A. et al., 2016). Accurate assessment of the levels and patterns of diversity can be invaluable in the analysis of genetic variability in cultivars (Smith, 1984; Cox et al., 1986), identification of diverse parental combinations to create segregating progenies with maximum genetic variability for further selection (Barrett and Kidwell, 1998) and in introgressing desirable genes into the available genetic base (Thompson et al., 1998).

Characterizing the extent and structure of crop genetic diversity is important to know the genetic variability available and its potential use in breeding programs. It is also important to devise appropriate sampling procedures for germplasm collection and conservation and the establishment of core collections (Brown, 1995; Hayward and Sackville-Hamilton, 1997; Ramanatha Rao and Hodgkin, 2002).

Analysis of the extent and distribution of genetic variations between and within populations in a crop are important to understand its evolution and to sample genetic resources for breeding and conservation purposes (Milligan et al., 1994, Lakkakula S., 2015).

In Ethiopia, A number of genetic variability studies of sorghum have been conducted using qualitative and quantitative traits. Significant variation for qualitative traits has been reported using 34 sorghum landraces obtained from five of the main sorghum growing areas of the country (Abdie et al., 2002, Mindaye TT et al., 2015). Similar findings have been reported using 59 Western Ethiopian sorghum landraces (Gebeyehu, 1993) and using 415 sorghum landraces with simple sequence repeats (SSR) and inter simple sequence repeats (ISSR) markers from four zones North Welo, South Welo, Oromiya and North Shewa (Haile Desmae et al., 2016).

\subsection{Sorghum breeding}

\subsubsection{Sorghum breeding in the world}

As explained in the previous section sorghum has diverse genetic variability. Conservation and understanding of the genetic structure of the world collections and breeding lines is essential to make them more accessible and useful for genetic improvement through pure line selection or crossing (Kimber, 2013). Many worldwide sorghum collections have been conserved in the USA and ICRISAT in addition to national collections maintained by individual countries where sorghum is important (Kimber et al., 2013; Kumar et al., 2011). However, only very small number of these collections has been well characterized and used by breeding programs (Kimber et al., 2013).

The type of farming system, production constraints and quality of end use product are vital in designing genetic improvement activities. Defining the breeding objective and creating genetic variability for the trait of interest are the primary and vital steps for effective crop genetic improvement (Haussmann et al., 2012). This can be done by designing crossing in targeted genomic regions between cultivated lines (Rooney, 2004) and wild relatives (Jordan et al., 2011a; Muraya et al., 2011) to find desirable traits. Different selections methods have been used in sorghum based on heritability of targeted traits and objectives of interest such as inbred line or hybrid. The pedigree breeding is the most commonly used for pure line development (Rooney et al., 2004). In this method segregating generations of the cross are made between parental lines which undergo repeated self pollinating and selection for the traits of interest until the lines maintain uniformity. The backcross method is used for the introgression of one or two desirable genes such as diseases resistance. Population improvement through recurrent selection can also be used to broaden the genetic basis and increase the frequency of favorable alleles in the breeding populations (Dweikat 2015).

The discovery of cytoplasmic male sterility in sorghum was used for commercial hybrid development in the USA. The higher performance of hybrids and the requirement for farmers to purchase F1 seed every season attracted private sector investment, with remarkable achievements being made in inbred and sorghum hybrid development over the past five decades in the USA, Australia and China (Jordan et al., 2003; Rakshit et al., 2014; Smith et al., 2010). Sorghum genotypes originating in tropical environments are late in maturity, tall in plant height and photoperiod sensitive and due to these not readily adaptable to the temperate environments. Changing of these genotypes into early maturing, short plant stature and photoperiod insensitive types was initiated in 1963 in the USA to make them suitable to the mechanized farming systems in the developed world (Stephen et al., 1967). The converted lines have been used as inbred parents for hybrid development in many developed countries (Klein et al., 2008, Smith et al., 2010) and increasingly their use is expanding to breeding programs in the developing world (Axtell et al., 1999).

The changing program was reinitiated in 2009 to exploit sorghum sequence information for rapid conversion of the exotic sorghum collections (Kimber et al., 2013). ICRISAT has also developed a number of varieties targeting the semi-arid tropics of Africa and Asia (Kumar et al., 2011). Inbred lines have been developed for hybrid breeding targeting Asia, which have also been started to be used by breeding programs Africa (Kumar et al., 2011, 
Reddy et al., 2007).

Allelic variation in recently released sorghum hybrids, and cultivars released in the 2000s, has been shown to have the lowest number of new alleles as compared to previously released hybrids (Smith et al., 2010). Therefore, there has been potential to expand the extent of genetic variability in improved lines using the world collections and the wild relatives as gene sources developed by ICRISAT (Upadhyaya et al., 2009, Ramu et al., 2013).

Increasing the efficiency and effectiveness of genetic improvement for complex traits, mainly grain yield, is the major interest in plant breeding especially in the developing countries. Following the discovery of molecular markers, a number of QTLs linked to quantitative traits in sorghum have been mapped (Rami et al., 1998; Mace and Jordan, 2011). Many QTLs linked to important traits have been identified over the past two decades including stay green (Crasta et al., 1999; Xu et al., 2000), striga resistance (Haussmann et al., 2004), fertility restoration (Klein et al., 2005; Jordan et al., 2011b) and photoperiod sensitivity (Chantereau et al, 2001; Crasta et al., 1999). The sequencing of the whole genome sorghum (Paterson et al., 2009) and resequencing multiple genotypes (Mace et al., 2013) in addition to the development of integrated QTL maps (Mace and Jordan, 2011) and a consensus map for major effect genes (Mace and Jordan, 2010) have been identified as useful resources for marker assisted breeding in sorghum (Gao et al., 2013). However, to-date the implementation of molecular markers in routine sorghum breeding activities has been found limited (Ejeta and Knoll, 2007).

\subsubsection{Sorghum breeding in Ethiopia}

The Ethiopian farmers have traditionally made selections of landrace genotypes adapted to particular environment and management practices such as intercropping (Georgis et al., 1990, Mindaye TT et al., 2015) with good quality traits such as larger grain size and different colors for various end uses and good plant biomass (Mekbib, 2006, ). Collection and conservation of the large number of sorghum landraces has been undertaken since 1970s and to date more than ten thousand sorghum collections are maintained in the EIB (Ethiopian Institute of Biodiversity) and the national sorghum improvement program in melkassa agricultural center (Kimber et al., 2013; Tanto and Abdi, unpublished). Ethiopia is also the major contributor for global sorghum collections at ICRISAT and in the US National Plant Germplasm System (Cuevas and Prom 2013; Dahlberg et al., 1997).

Sorghum breeding activities in Ethiopia began in the early 1950s (Gebrekidan, 1980). Pure line selections and pedigree breeding have been the major breeding activities targeting the three major agro ecologies for the past decades. Using these methods a number of open pollinated sorghum varieties have been released for production (Gebeyehu et al., 2004). However, these varieties have had very low adoption rates to-date due to weak extension system (Cavatassi et al., 2011). The major factor for poor adoption is due to improved varieties lack farmers preferred traits such as plant height, grain size etc. (Beyene, 2012; Mekbib, 2006; Wubeneh and Sanders, 2006). The eighty five percent of the improved varieties released for the lowland and intermediate environments developed using introduced lines and their characteristics are short plant stature, early maturity and lower grain size (Adugna, 2007, Mekbib, 2006). In contrast, all the varieties released for the highland environment have been pure lines selected from the highland landrace collections; however, these released improved varieties only have limited yield advantage compared to the farmers' selected varieties or landraces which is one of the factors attributed to their lower adoption rate by farmers (Mekbib, 2006). Fifty two sorghum varieties has been released (forty eight are open pollinated and four are hybrid varieties) from the past to date in Ethiopia (Melkassa unpublished manual).

\subsection{Sorghum improvement}

Sorghum can be genetically transformed by using Agrobacterium (Alina M. et al., 2017) to improve nutritional quality due to it's low in lysine content, a high-lysine gene HT12 can be inserted into the sorghum gene using Agrobacterium vector together with a herbicide resistant gene bar. This way can increase $40-60 \%$ of lysine (Zhao et al., 2003). The benefit of improved transgenic lysine variety is to eradicate malnutrition. Africa Biofortified Sorghum (ABS) project developed improved sorghum lines through the process of genetic engineering techniques (Africa Biofortified Sorghum Project, 2009). The transgenic lines had high protein digestibility, improved amino acid score, and protein digestibility corrected amino acid score in contrast to untransformed sorghum lines (Vendemiatti et al., 2008). However, in Ethiopia, genetic engineering has not been yet done to improve sorghum. Stay-green QTLs were introgressed from improved to the farmer preferred Ethiopian local sorghum varieties and eight lines were advanced to the next esting (Asfaw A. and Alemu T., 2014). The Ethiopian breeding program used molecular markers to begin rapidly introducing a major gene for resistance to Striga into locally adapted landraces. 359 plants were advanced to the next level of testing(Melkassa unpublished progress report, 2015/2016). Genetic progress achieved over time from a breeding program is useful to develop effective and efficient breeding strategies by assessing the efficiency of past improvement works in genetic yield potential and suggest on future selection direction to facilitate further improvement (Abeledo et al., 2003, Mihret Y., 2015). Due to an excellent adaptation to drought, water logging and salinity, sorghum can grow in poor soils where growth of other cereals such as maize cannot be possible (ICRISAT, 1996, Lakkakula S., 2015). Therefore, the genetic improvement of sorghum for tolerance to drought and salinity through breeding would help to further increase its productivity in 
soils prone to drought and salinity.

\section{Summary and Conclusion}

In general, having diverse sorghum genetic diversity is important to increase genetic improvement of sorghum for many desirable traits, mainly for yield through breeding using advanced tools. However, in Ethiopia, progress is slow because of shortage of trained man power, infrastructure, conventional plant breeding etc. As the potential of genetic diversity in Ethiopia, the research is carried out in our country by scientists/researchers based at higher learning institutions and research institute. Hence, we can exploit the genetic potential of sorghum for high productivity, quality and production in our country. In spite of its prime importance in the Ethiopian agriculture, the major bottlenecks constraining production of sorghum are lack of high yielding and stable varieties, lack of improvement works in genetic yield potential , abiotic stresses such as drought, soil fertility decline (Gebrekidan H. 2003). In addition, Biotic stresses such as diseases, insects and weeds (especially Striga).The major areas of focus in the future sorghum genetic improvement include: advancing human capacity, improving productivity of sorghum, improving quality of sorghum, developing of tolerance/resistance to abiotic stresses using biotechnological tools such as molecular markers etc., and Developing of tolerance/resistance to biotic stresses such as diseases, insects, weeds etc.

\section{Acknowledgements}

The reviewer acknowledged the Researchers who had studied improvement of sorghum genetics in Ethiopia in early 1950s in absence of facilities.

\section{References}

Abe Sh. (2010). Biodiversity in Plant, Grain and Nutritional Characteristics of Sorghum [Sorghum bicolor (L.) Moench] Accessions From Ethiopia and South Africa; Thesis work Department of Plant Breeding, University of the Free State Bloemfontein, South Africa. pp 1- 10.

Abdie A, Bekele E, Asfaw Z, Teshome A. (2002). Pattern of morphological variation of sorghum (Sorghum bicolor (L) Moench) landraces in qualitative characters in North Showa and south Wello. Hereditas 137: 161-172.

Abeledo, L. G., Calderini, D. F. and Slafer, G. A. (2003). Genetic improvement of barley Yield potential and its physiological determinants in Argentina (1944-1998). Euphytica, 130, 325-334.

Africa Biofortified Sorghum (2009). Africa biofortified sorghum project.DOI: http:/biosorghum.org/.

Agrama HA, Tunistra MR. (2003). Phylogenetic diversity and relationships among sorghum accessions using SSRs and RAPDs. Afr J Biotec 2:334 - 340 .

Ahnert D, Lee M, Austin DF, Livini C, Woodman WL, Openshaw SJ, Smith JSC, Porter K, Dalton G. (1996). Genetic diversity among elite sorghum inbred lines assessed with DNA. Crop Sci 36:1385-1392.

Ali ML, Rajewski JF, Baenziger PS, Gill KS, Eskridge KM, Dweikat I. (2008). Assessment of genetic diversity and relationship among a collection of US sweet sorghum germplasm by SSR markers. Mol Breeding.;21(4):497-509.doi:10.1007/s11032-007-9149-z.

Asfaw A. and Alemu T. (2014). Response of stay-green quantitative trait locus introgression of sorghum lines to post anthesis drought stress. Vol.13(49),pp.4492-4500.

Assefa, Y.S., Staggenborg, A. and Prasad, P.V.V. (2010). Grain sorghum water requirement and responses to drought stress: A review. On-line. Crop Management doi: 10.1094/CM-20101-1109-01-RV.

Axtell J, Kapran I, Ibrahim Y, Ejeta G, Andrews DJ. (1999). Heterosis in sorghum and pearl millet. In: Proceedings of the genetic and exploitation of heterosis in crops. ASA-CSSASSSA, 677 South Segoe Road, Madison, WI. 53711, USA. pp. 375-386.

Barrett BA, Kidwell KK. (1998). AFLP-based genetic diversity assessment among wheat cultivars from the Pacific Northwest. Crop Sci. 38:1261-1271.

Billot C, Ramu P, Bouchet S, Chantereau J, Deu M, Gardes L, Hash CT. (2013). Massive sorghum collection genotyped with SSR markers to enhance use of global genetic resources. PLoS One 8:e59714.

Botstein D, White RL, Skolnick MH, Davies RW. (1980). Construction of a genetic map in man using restriction fragment length polymorphism. Am J Hum Genet 32: 314-331

Brown AHD. (1995). The core collection at the crossroads. In: Hodgkin T, Brown AHD, van Hintum ThJL, Morales EAV (eds.). Core collection of Plant Genetic Resources, IPGRI pp. 319.

Brown PJ, Myles S, Kresovich S. (2011). Genetic Support for Phenotype-based Racial Classification in Sorghum. Crop Sci 51:224-230.

Casa AM, Pressoir G, Brown PJ, Mitchell SE, Rooney WL, Tuinstra MR, et al. (2008). Community resources and strategies for association mapping in sorghum.Crop Sci.:48(1):30-40.

Central Statistical Agency of Ethiopia (CSA) (2017). Agricultural Sample Survey 2016/2017. Stat Bull, 584.

TCox TS, Murphy JP, Rodgers DM. (1986). Changes in genetic diversity in the red winter wheat regions of the United States. Proc. Natl. Acad.Sci. USA. 83:5583-5586. 
Cuevas HE, Prom LK, Erpelding JE, Brotons V. (2014). Assessments of genetic diversity and anthracnose disease response among Zimbabwe sorghum germplasm. Plant Breed.;133:234-42. doi:10.1111/pbr.12133.

Cuevas HE, Prom LK. (2013). Assessment of molecular diversity and population structure of then Ethiopian sorghum [Sorghum bicolor (L.) Moench] germplasm collection maintained by the USDA-ARS National Plant Germplasm System using SSR markers. Genet Resour Crop Ev 60:1817-1830.

Dahlberg JA, Burke JJ, Rosenow DT. (2004). Development of a sorghum core collection: refinement and evaluation of a subset from Sudan. Econ Bot 58:556-567.

Deu M, Rattunde F, Chantereau J. (2006). A global view of genetic diversity in cultivated sorghums using a core collection. Genome 49:168-180.

Dicko, M.H., Gruppen, H., Traore, A.S., Alphons, G.J., Voragen, A.G.J. and Berkel, W.J.H.van. (2006). Sorghum grain as human food in Africa: Relevance of content of starch and amylase activities. African Journal of Biotechnology, 5: 384-395.

Dillon, S.L., Lawrence, P.K., Henry, R.J., Ross, L., Price, H.J., Johnston, J.S. (2004). Sorghum laxiflorumand S. macrospermum, the Australian native species most closely related to the cultivated S. Bicolor based on ITS1 and NDHF sequence analysis of 25 Sorghum species. Plant Syst. Evol. 249, 233-246.

Dillon SL, Shapter FM, Henry RJ, Cordeiro G, Izquierdo L, Lee LS (2007). Domestication to Crop Improvement: Genetic Resources for Sorghum and Saccharum (Andropogoneae). Ann Bot 100:975-989.

Doggett H. (1988). Sorghum. $2^{\text {nd }}$ ed. Longman Group UK Limited.

DeWet, J.M.J. (1978). Systematics and evolution of Sorghum sect. bicolor (Gramineae). American Journal of Botany, 65: 477-484.

Dweikat I. (2015). Sorghum breeding. In: Wang YH, Upadhyaya HD, Kole C (eds) Genetics, Genomics and Breeding of sorghum. pp 90-113.CRC Press, New York.

Edwards D, Batley J, Snowdon RJ. (2013). Accessing complex crop genomes with next-generation sequencing. Theor Appl Genet 126:1-11.

EIAR (Ethiopian Agricultural Research Institute) [2014]. Ethiopian Strategy for Sorghum. EIAR, Addis Ababa, Ethiopia Pp28.

Elshire RJ, Glaubitz JC, Sun Q, Poland JA, Kawamoto K, Buckler ES, et al. (2011). A robust, simple genotypingby-sequencing (GBS) approach for high diversity species. Plos One.:6(5):e19379.

FAO (2005). http://faostat.fao.org/site/408/default.aspx.

Food and Agriculture organization of the United Nation statistical division (FAOSTAT), 2015. http://faostat3.fao.org/home/E

Garcia AA, Benchimol LL, Barbosa AM, Geraldi IO, Souza Jr CL, Souza APD. (2004). Comparison of RAPD, RFLP, AFLP and SSR markers for diversity studies in tropical maize inbred lines. Genet Mol Biol 27: 579588.

Gebeyehu G. (1993). Characterization and evaluation of sorghum (Sorghum bicolor (L.) Moench) germplasms collected from Gambella. MSc Thesis. Alemaya University of Agriculture, Ethiopia.

Gebeyehu G, Asfaw A, Taye T, Tesefaye T, Ketema B, Hailemichael H. (2004). Development of sorghum varieties and hybrids for dry land areas of Ethiopia. Uga J Agri Sci 9:594-605

Gebrekidan H (2003). Grain Yield Response of Sorghum (Sorghum bicolor) to Tied Ridges and Planting Methods on Entisols and Vertisols of Alemaya Area, Eastern Ethiopian Highlands

Georgis K, Abebe A, Negasi A et al. (1990). Cereal-legume intercropping research in Ethiopia. In: Waddington SR, Palmer AFE, Edje OT (eds) Research methods for cereal legume intercropping. Proc. Workshop on Research Methods for Cereal/Legume Intercropping in Eastern and Southern Africa. CIMMYT. p167-175.

Gilding EK, Frere CH, Cruickshank A, Rada AK, Prentis PJ, Mudge AM, Godwin ID, et al . (2013). Allelic variation at a single gene increases food value in a drought-tolerant staple cereal. Nat Commun 4:1483.

Grenier C, Bramel-Cox PJ, Noirot M, Prasada Rao KE, Hamon P. (2000). Assessment of genetic diversity in three subsets constituted from the ICRISAT sorghum collection using random vs nonrandom sampling procedures A. Using morpho-agronomical and passport data. Theor Appl Genet 1001:190-196.

Grenier C, Bramel-Cox PJ, Hamon P. (2001). Core collection of sorghum: I.Stratification based on ecogeographical data. Crop Sci:234-40.

Gupta PK, Rustgi S, Mir RR. (2008). Array based high throughput DNA markers for crop improvement. Heredity 101:5-18.

Haile Desmae, David R. Jordan and Ian D. Godwin (2016). DNA markers reveal genetic structure and localized diversity of Ethiopian sorghum landraces. Vol. 15(41), pp. 2301-2311.

Haussmann BIG, Mahalakshmi V, Reddy BV et al. (2002). QTL mapping of stay-green in two sorghum recombinant inbred populations. Theor Appl Genet 106:133-142.

Haussmann BIG, Rattunde HF, Weltzien ER, Traore', vom Brocker K., Parzies HK. (2012). REVIEW, Breeding Strategies for Adaptation of Pearl Millet and Sorghum to Climate Variability and Change in West Africa. J Agro Crop Sci 198:327-339. 
Hayward MD, Sackville Hamilton NR. (1997). Genetic Diversity: Population Structure and Conservation. In: Callow JA, Ford-Lloyd BV, Newbury HJ (Eds.). Biotechnology and plant genetic resources Conservation and uses. CAB Int. pp. 49-76.

Hugo E. Cuevas, Giseiry Rosa-Valentin, Chad M. Hayes, William L. Rooney, and Leo Hoffmann (2017). Genomic characterization of a core set of the USDA-NPGS Ethiopian sorghum germplasm collection: implications for germplasm conservation, evaluation, and utilization in crop improvement. USDA-ARS, Tropical Agriculture Research Station, 2200 Pedro Albizu Campos. DOI 10.1186/s12864-016-3475-7.

ICRISAT (1996). The World Sorghum and Millet Economies: Facts, Trends and Outlook. ICRISAT/FAO, Patancheru, India/Rome, Italy, pp. 1-2.

ICRISAT (International Crop Research Institute for Semi-Arid Tropics) [2005]. Sorghum report. http://www.icrisat.org/text/research/grep/homepage/sorghum/sorghumhomepage.htm Online. Patancheru, India.

Jordan DR, Tao Y, Godwin ID, Henzell RG. (2003). Prediction of hybrid performance in grain sorghum using RFLP markers. Theor Appl Genet 106:559-567.

Jordan DR, Mace ES, Cruickshank AW, Hunt CH, Henzell RG. (2011a). Exploring and Exploiting Genetic Variation from Unadapted Sorghum Germplasm in a Breeding Program. Crop Sci 51:1444-1457.

Kebede Y, Menkir A. (1987). Current activities, research recommendations and future strategies of sorghum improvement programme in Ethiopia. In: Proceedings of the 19th National Crop Improvement Conference, 22-26 April, 1987 Addis Ababa, Ethiopia.

Kebede, Y. (1991). The role of Ethiopian sorghum germplasm resources in the national breeding program. In: J.M., Engels, J. G. Hawke and M. Worede, (Eds.), Plant Genetic Resources of Ethiopia. Cambridge University Press, Cambridge, 315-322 pp.

Kebede H, Subudhi PK, Rosenow DT et al. (2001). Quantitative trait loci infl uencing drought tolerance in grain sorghum (Sorghum bicolor L. Moench). Theor Appl Genet 103:266 276.

Kimber CT, Dahlberg JA, Kresovich S. (2013). The Gene Pool of Sorghum bicolor and Its Improvement. In: Paterson A.H. (ed.) Genomics of the Saccharinae, Plant Genetics and Genomics: Crops and Model. 23-41, Springer Science, Media New York.

Klein RR, Mullet JE, Jordan DR, Miller FR, Rooney WL, Menz MA, Franks CD, Klein P E . (2008). The effect of Tropical Sorghum conversion and Inbred Development on Genome diversity as revealed by HighResolution Genotyping. Crop Sci 48-S12 - S26

Kumar AA, Reddy BVS, Sharma HC, Hash CT, Rao PS, Ramaiah B, Reddy PS., 2011. Recent advances in sorghum genetic enhancement research at ICRISAT. Am J Plant Sci 2:589 600.

Lazarides, M., Hacker, J.B. and Andrew, M.H. (1991). Taxonomy, cytology and ecology of indigenous Australian sorghums (Sorghum Moench: Andropogonae: Poaceae). Australian Botany, 4, 591-635.

Mace ES, Tai S, Gilding EK, Li Y, Prentis P, Bian L, Campbell B, Hu W, Innes DJ, Han X. et al . (2013). Wholegenome sequencing reveals untapped genetic potential in African's indigenous cereal crop sorghum. Nat Commun 4:2320.

Milligan, B.G., Leebens-Mack, J., Strand, A.E. (1994). Conservation genetics: beyond the maintenance of marker diversity. Mol. Ecol. 3, 423-435.

Mohammadi SA, Prasanna BM. (2003). Analysis of genetic diversity in crop plants - Salient statistical tools considerations. Crop Sci.43:1235-1248.

Morris GP, Ramu P, Deshpande SP, Hash CT, Shah T, Upadhyaya HD, Kresovich S . (2013). Population genomic and genome-wide association studies of agro climatic traits in sorghum. Proc Natl Acad Sci USA, 110:453458.

Muraya MM, Geiger HH, Sagnard F, Toure L, Traore PCS, Togola S, Parzies HK et al. (2011). Adaptive values of wild $\times$ cultivated sorghum (Sorghum bicolor (L.) Moench) hybrids in generations F1, F2, and F3. Genet Resour Crop Ev 59:83-93.

Newbury HJ, Ford-Lioyd BV. (1997). Estimation of genetic diversity. In: Maxted N., Ford-Lloyd B.V and Hawkers J.G. (eds). Plant genetic conservation-the insitu approach. pp:192-206.

Packer D J, Rooney WL. (2014). High-parent heterosis for biomass yield in photoperiod-sensitive sorghum hybrids. Field Crop Res 167:153-158.

Perumal R, Krishnaramanujam R, Menze MA, Katilé S, Dahlberg J, Magill CW, Rooney WL . (2007). Genetic diversity among Sorghum races an Working groups based on AFLPs and SSRs. Crop Sci 47:1375-1383.

Pejic I, Ajmone-Marsan P, Morgante M, Kozumplick V, Castiglioni P, Taramino G, Motto M . (1998). Comparative analysis of genetic similarity among maize inbred lines detected by RFLPs, RAPDs, SSRs, and AFLPs. Theor Appl Genet 97:1248-1255.

Poland 2012 JA, Rife TW. (2012). Genotyping-by-sequencing for plant breeding and genetics. The Plant Genome: doi: 10.3835/plantgenome2012.05.0005.

Prasada Rao KE, Mengesha MH. (1981). A pointed collection of zera-zera sorghum in the Gambella area of 
Ethiopia. Genetic Resources Units Progress Rep. No. 33. ICRISAT, Patancheru,India.

Prasad, P.V.V. and Staggenborg, S.A. (2009). Growth and production of sorghum and millets. In soils, plant growth and crop production -Volume II. In: Encyclopedia of Life Support Systems, Eolss Publishers, Oxford, UK. http:// www.eolss.net. Access data.

Rakshit S, Hariprasanna K, Gomashe S, Ganapathy KN, Das IK, Ramana OV, Dhandapani A, Patil JV. (2014). Changes in Area, Yield Gains, and Yield Stability of Sorghum in Major Sorghum Producing Countries, 1970 to 2009. Crop Sci 54:1571-1584.

Ramanatha Rao VR, Hodgkin T. (2002). Genetic diversity and conservation and utilization of plant genetic Resources. Plant Cell, Tissue and Organ Cult. 68:1-19.

Ramu P, Billot C, Rami JF, Senthilvel S, Updahyaya HD, Reddy LA, Hash CT. (2013). Assessment of genetic diversity in the sorghum reference using EST-SSR markers. Theor Appl Genet 126:2051-2064.

Reddy VG, Rao NK, Reddy BS, Prasada Rao KE. (2002). Geographic distribution of Basic and Intermediate races in the World Collection of Sorghum Germplasm. Int Sorghum Millets Newsl 43:15-16.

Reddy B, Ramesh S, Reddy S, Ramaiah B, Salimath P, Kachapur R. (2005a). Sweet sorghum a potential alternate raw material for bio-ethanol and bio-energy. Int Sorghum Millets Newsl 46:79-86.

Reddy BVS, Ramesh S, Reddy PS, Ramaiah B. (2007). Combining ability and heterosis as influenced by malesterility inducing cytoplasms in sorghum [Sorghum bicolor (L.) Moench]. Euphytica 154:153-164.

Reddy VG, Upadhyaya HD, Gowda CLL. (2006). Current status of sorghum genetic resources at ICRISAT:Their sharing. Int Sorghum Millets Newsl 47: 9-13.

Rooney WL. (2004). Sorghum Improvement-Integrating Traditional and New Technology to Produce Improved Genotypes. In: Advance in agronomy. 83: 37-109

Singh R, Axtell JD. (1973). High lysine mutant gene (hl) that improves protein quality and biological value of grain sorghum. Crop Sci 13:535-539.

Smith CW, Frederiksen RA (2000). History of cultivar development in the United States: From "memories of A.B. Maunder - Sorghum breeder". In: Smith CW, Fredriksen RA (eds) Sorghum: Origin, history, technology and production. pp 191-223

Smith JSC. (1984). Genetic variability within U.S. hybrid maize: Multivariate analysis of isozyme data. Crop Sci. 24:1041-1046.

Smith S, Primomo V, Monk R, Nelson B, Jones E, Porter K. (2010). Genetic diversity of widely used US sorghum hybrids 1980-2008. Crop Sci 50:1664-1673.

Sun, Y., Chen, S.Q., Liang, G.H. (1994). Induction of autopolyploid plants of Sorghum bicolor. Cytology 59, 109114.

Stephens JC, Miller FR, Rosenow DT. (1967). Conversion of alien sorghums to early combine genotypes. Crop Sci 7:396.

Tautz D, Trick M, Dover GA. (1986). Cryptic simplicity in DNA is a major source of genetic variation. Nature 322:652-656.

Teshome A, Baum BR, Fahrig L, Torrance JK, Arnason TJ, Lambert JD. (1997). Sorghum(Sorghum bicolor (L.) Moench) landrace variation and classification in North Shewa and South Welo, Ethiopia. Euphytica 97: 255263.

Teshome, A., Patterson, D., Torrance, J. K. and Arnason, J.T. (2007). Changes of Sorghum bicolor landrace diversity and farmers' selection criteria over space and time, Ethiopia. Genetic resource and crop evolution. $54: 1219-1233$

Tesso T, Tirfessa A, Mohammed H. (2011). Association between morphological traits and yield components in the durra sorghums of Ethiopia. Hereditas 148:98-109.

Thompson JA, Nelson RL, Vodkin LO. (1998). Identification of diverse soybean germplasm using RAPD markers. Crop Sci. 38:1348-1355.

Tolk JA, Howell TA, Miller FR. (2013). Yield component analysis of grain sorghum grown under water stress. Field Crop Rese 145:44-51.

Upadhyaya HD, Pundir RPS, Dwivedi SL, Gowda CLL, Reddy VG, Singh S. (2009). Developing a mini core collection of sorghum for diversified utilization of germplasm.Crop Sci.;49(5):1769-80.

USDA-ARS NGRP (2015). Germplasm Resources Information Network- (GRIN) [Online Database]. National Germplasm Resources Laboratory, Beltsville, Maryland., https://npgsweb.arsgrin.gov/gringlobal/search.aspx.

Vavilov, N.I. (1951). The origin, variation, immunity and breeding of cultivated plants. Chron. Bot., 13: 1-366.

Vendemiatti A, Ferreira RR, Gomes LH, Medici LO, and Azevedo RA. (2008). Nutritional quality of sorghum seeds: storage proteins and amino acids. Food Biotech . 22: 377- 397.

Vos P, Hogers R, Bleeker M, Reijans M, Van de Lee T, Hornes M, Frijters A, Pot J, Peleman J, Kuiper M, Zabeau M. (1995). AFLP: A new technique for DNA. fingerprinting. Nucleic Acids Res 23:4407-4414.

Wang ML, Chengsong Z, Barkley NA, Chen Z, Erpelding JE, Murray SC, et al. (2009). Genetic diversity and 
population structure analysis of accessions in the US historic sweet sorghum collection. Theor Appl Genet.:120:13-23. doi:10.1007/s00122-009-1155 6.

Wang YH, Upadhyaya HD, Burrell AM, Sahraeian SM E, Klein RR, Klein PE. (2013). Genetic structure and linkage disequilibrium in a diverse, representative collection of the $\mathrm{C} 4$ model plant, Sorghum bicolor. G3: Genes| Genomes| Genetics 3:783-793.

Williams JGK, Kubelik RA, Livak KJ, Rafalski JA, Tingey SV. (1990). DNA polymorphisms amplified by arbitrary primers are useful as genetic markers. Nucleic Acids Res 18:6531 6535.

Worede, M., Tesemma, T. and Feyissa, R. (2000). Keeping diversity alive:An Ethiopian perspective. In: Brush, S.B. (Ed.), Genes in the field: On-farm conservation of crop diversity, Lewis Publishers, Boca Raton, pp. 143-161.

Wortmann CS, Mamo M, Mburu C, Letayo E, Abebeb G, Kayuki KC, Chisi M, Mativavarira M,

Xerinda S, Ndacyayisenga T. (2009). Atlas of sorghum production in Eastern and Souther Africa. The University of Nebraska. 